\title{
PENGARUH PEMBERIAN RANSUM DENGAN CEMARAN INSEKTISIDA ORGANOFOSFAT TERHADAP AKTIVITAS ENSIM KHOLIN ESTERASE DAN PRESTASI ITIK
}

\author{
Lies Mira Yusiati ${ }^{1}$
}

\section{INTISARI}

Penelitian ini dilakukan dengan tujuan untuk mengetahui pengaruh cemaran diazinon suatu insektisida yang masuk dalam kelompok organofosfat terhadap aktivitas ensim kholin esterase pada itik. Karena gangguan aktivitas ensim dapat mempengaruhi metabolisme dalam tubuh maka diteliti pula penganuhriya terhadap gambaran darah, konsumsi, produksi telur dan komposisi kimia daging. Dalam penelitian ini digunakan 24 ekor itik betina dewasa yang dibagi menjadi 3 kelompok perlakuan ransum, Kelompok I itik memperoleh ransum dengan cemaran diazinon 0 ppm, kelompok II 0,03 ppm sedang kelompok III $14 \mathrm{ppm}$. Pada awal penelitian diambil sampel darah dari 4 ekor itik untuk masing-masing kelompok perlakuan, kemudian ditentukan aktivitas kholin esterasenya. Disamping itu diambil juga darah dari 3 ekor itik untuk dilihat gambaran darahnya yang meliputi kadar $\mathrm{Hb}, \mathrm{RBC}, \mathrm{PCV}, \mathrm{MCH}$ dan MCHC serta kadar kholesterolnya. Setiap minggu sekali mulai hari ke-30 diambil sampel telur dari masing-masing kelompok untuk ditentukan kandungan kholesterolnya. Pada akhir penelitian diambil 3 ekor itik secara acak dari masing-masing kelompok untuk dipotong dan diambil sampel daging dari otot Pectoralis superficialis (PS) dan Biceps femoris (BF) untuk ditentukan komposisi kimianya yang meliputi protein kasar, lemak kasar dan abu secara proksimat Hasil penelitian menunjukkan aktivitas kholin esterase rata-rata untuk kelompok I, II, III berturut-turut sebesar 2,117, 1,754 dan 2,268 KU/l, dengan perbedaan yang tidak bermakna. Jumlah RBC darah itik kelompok PI, PII, dan PIII berturut turut sebesar 2,60, 2,85 dan 2,80 x 10 12 $/$, kadar $\mathrm{Hb} 9,1,10,3$ dan $8,9 \mathrm{~g} / \mathrm{dl}$., PCV sebesar 36,3, 39,0 dan 37,0\%. MCH sebesar 36,60, 36,83 dan 32,02 pg sedangkan MCHC sebesar $24,94,26,53$ dan $24,24 \mathrm{~g} / \mathrm{dl}$. Hasil penelitian menunjukkan perbedaan yang tidak bermakna pada gambaran darah, konsumsi maupun produksi. Kadar kholesterol darah tidak terpengaruh secara bermakna oleh cemaran diazinon namun kadar kholesterol telur turun dari 279,82 menjadi 174,62 dan $128,39 \mathrm{mg} / 100 \mathrm{~g}$ kuning telur $(\mathbf{P}<0,01)$. Komposisi kimia daging kelompok I, II dan III berbeda tidak bermakna. Dari hasil tersebut dapat disimpulkan bahwa cemaran diazinon sebesar $0,03 \mathrm{ppm}$ dan $14 \mathrm{ppm}$ tidak memberikan pengaruh terhadap aktivitas kholin esterase, $\mathrm{MCH}$ dan
$\mathrm{MCHC}$ itik.

(Kata Kunci : Insektisida Organofosfat, Diazinon, Kholin Esterase, Itik).

Buletin Peternakan 23 (3) : $127-132,1999$

'Fakultas Peternakan Universitas Gadjah Mada, Yogyakarta 55281. 


\section{THE EFFECT OF ORGANOPHOSPHATE INSECTICIDE CONTAMINATED DIET ON CHOLIN ESTERASE ACTIVITY AND DUCK PERFORMANCE}

\section{ABSTRACT}

The experiment was conducted with 24 local female ducks to examine the effect of diazinon, a member of organophosphate insecticide group on the activity of cholin esterase as well as duck's performance included feed consumption, egg production, blood profile, egg cholesterol content and chemical composition of meat. The birds were divided into three groups named DI which were offered diet without diazinon (control diet), DII and DIII which were offered diet contained $0.03 \mathrm{ppm}$ and $14 \mathrm{ppm}$ of diazinon each respectively. At the beginning of the experiment blood sample were taken from four ducks in every group for cholin esterase determination. Blood samples for determination of cholesterol content and blood profile was taken from another three birds in each group. Blood profile includes Red Blood Cell (RBC), Hemoglobin (Hb), Packed Cell Volume (PCV), Mean Corpuscular Hemoglobin (MCH) and Mean Corpuscular Hemoglobin Concentration (MCHC). The same procedure of blood sample collection was applied on the $30^{\text {th }}$ and $60^{t_{1}}$ days to the same respected birds. Egg samples were taken once a week began at the $30^{t_{1}}$ up to the $60^{\text {th }}$ days, for cholesterol determination. At the end of the diet treatment three birds were taken from each group for determination meat chemical composition. The result showed that cholin esterase activity of the control birds (DI) was not different compared with those of birds from DII and DIII (2.117 KU/l vs. 1.75 and $2.059 \mathrm{KU} /$ ). Blood profile, feed intake, egg production as well as chemical composition of meat didn't alter by the diazinon contaminated diet. Although the cholesterol content of blood were not different among the treatments, cholesterol content of egg produced by the control bird (DI) were higher than those produced by the birds received diazinon contaminated diet $(279.82 \mathrm{mg} / 100 \mathrm{~g}$ vs. 174.62 and $129.39 \mathrm{mg} / 100 \mathrm{~g})$. It Could be concluded that although up to the level of $14 \mathrm{ppm}$, diazinon in the diet decreased egg cholesterol, the doses still has no affect on cholin esterase activity, duck performance, blood profile and meat composition.

(Key Words: Insecticide, Organophosphate, Diazinon, Cholin Esterase, Duck).

\section{Pendahuluan}

Peternakan itik di Indonesia sebagian masih menggunakan cara ekstensif, yaitu itik digembalakan di sawah dari satu tempat ke tempat yang lain untuk mendapatkan makanan. Dengan sistem pemeliharaan tersebut memungkinkan itik yang dipelihara mengkonsumsi sisa panen di persawahan yang tercemar oleh insektisida, mengingat sebagian besar petani menggunakan insektisida untuk mencegah serangan hama dalam rangka peningkatan produksi pertanian.

Dari hasil penelitian dilaporkan bahwa terdapat residu diazinon dalam beberapa sayuran dan buah-buahan hasil pertanian air selokan disekitar sawah maupun air pada saluran irigasi serta tanah dibeberapa daerah dimana petani menggunakan senyawa tersebut sebagai insektisida (Soehardi dan Sumatera, 1982 ; Oksawa dkk., 1985 ; Simon, 1984). Miller (1963) mengelompokan insektisida menjadi beberapa golongan yaitu kelompok hidrokarbon klorid, organofosfat, organothiosianat, insektisida anorganik dan botanik. Yang termasuk organofosfat diantaranya adalah dipterex, chlortion, malathion, parathion, americansianamit dan diazinon. Hodgson dan Guthrie (1976) menyatakan bahwa ensim esterase dibagi dalam dua kelas yaitu esterase tipe A yang bersifat tidak peka terhadap hambatan ester organofosfat dan esterase tipe B yang bersifat peka terhadap hambatan ester organofosfat. Yang termasuk tipe B diantara- 
nya adalah ensim kholin esterase, asetilkholin esterase, karboksil esterase dan lipase. Hambatan ensim kholin esterase oleh senyawa fosfat organik dapat menyebabkan kematian karena timbulnya paralisis pada sistem pernafasan (Stryer, 1975). Hal ini nampaknya disebabkan tidak aktifnya ensim kholin esterase yang dapat mengakibatkan akumulasi asetil kholin pada junction neuromuscular.

Berdasarkan uraian di atas perlu dilakukan suatu penelitian untuk mengetahui pengaruh cemaran insektisida organofosfat diazinon terhadap aktivitas ensim esterase dan prestasi itik.

\section{Materi dan Metode}

Dalam penelitian ini digunakan 24 itik lokal betina dengan bobot badan yang seragam. Itik dibagi secara acak menjadi 3 kelompok perlakuan sehingga masing-masimg kelompok terdiri dari 8 ekor. Kelompok P I itik memperoleh ransum tanpa cemaran diazinon, P II itik memperoleh ransum cemaran diazinon $0.03 \mathrm{ppm}$ dan P III itik memperoleh ransum dengan cemaran diazinon 4 ppm. Itik dipelihara dalam kandang berlantai litter yang dilengkapi halaman untuk umbaran disiang hari. Pakan dan minum diberikan secara ad libitum. Pakan yang diberikan terdiri dari campuran jagung, bekatul dan konsentrat dengan perbandingan $30: 30: 40$. Hasil analisis proksimat ransum adalah kadar air $10,85 \%$, protein kasar 15,03, lemak kasar 9,76, serat kasar $5,75, \mathrm{Ca} 2,85$ dan fosfor $1,70 \%$. Itik dipelihara selama 60 hari dan selama penelitian dicatat konsumsi pakan dan produksi telur. Pada awal penelitian diambil sampel darah dari empat ekor itik yang dipilih secara random dari masing-masing kelompok untuk penentuan aktivitas ensim kholin esterase, sedang untuk penentuan gambaran darah yang meliputi kadar hemoglobin ( $\mathrm{Hb})$, Red Blood Cell (RBC), Packed Cell Volume (PCV), Mean Corpuscular Hemoglobin $(\mathrm{MCH})$ dan Mean Corpuscular Hemoglobin Concentration (MCHC) dan kadar kholesterol diambil sampel darah dari 3 ekor itik dari masingmasing kelompok, dan pengambilan sampel darah diulang lagi setelah 30 dan 60 hari Sampel darah diambil dari vena didaerah sayap. Sampel telur diambil setiap satu minggu sekali mulai hari ke-30 sampai hari ke-60 untuk ditentukan kandungan kholesterolnya. Penentuan kadar kholesterol telur dan darah dilakukan secara spektrofotometrik dengan metode Lieberman Burchard (Plummer, 1977). Pada akhir penelitian diambil 3 ekor itik secara acak dari masing-masing kelompok untuk dipotong dan diambil sampel daging dari otot Pectoralis superficialis (PS) dan Biceps femoris (BF) untuk ditentukan komposisi kimianya yang meliputi protein kasar, lemak kasar dan abu secara proksimat (Harries, 1970).

Data gambaran darah dan aktivitas kholin esterase dianalisis dengan analisis variansi menggunakan CRD pola split unit sebagai rancangannya, sedangkan data komposisi kimia daging dan kholesterol telur menggunakan CRD pola factorial yang kemudian diikuti dengan Duncan's New Multiple Range Tesi (DMRT).

\section{Hasil Penelitian}

\section{Aktivitas kholin esterase, konsumsi pakan dan produksi telur}

Hasil penentuan aktivitas ensim kholin esterase senum darah itik disajikan dalam Tabel 1.

Hasil penelitian menunjukkan perbedaan yang tidak bermakna pada aktivitas kholin esterase serum darah itik karena pegaruh cemaran insektisida diazinon sampai aras 14 ppm dalam ransum yang telah dikonsumsi selama 60 hari. Rata-rata konsumsi itik perlakuan I, II dan III berbeda tidak bermakna yaitu sebesar 200,12, 198,51 dan 197,78 gram/ekor/hari. Pada kelompok P III kadar diazinon dalam ransum $14 \mathrm{ppm}$ atau $14 \mathrm{mg} / \mathrm{kg}$ pakan, jadi konsumsi diazinon per ekor per hari sebesar $2,77 \mathrm{mg}$. Dengan berat itik ratarata $1,8 \mathrm{~kg}$ maka konsumsi diazinon sebesar $1,54 \mathrm{mg} / \mathrm{kg}$ bobot badan. Dosis letal (LD, diazinon untuk itik sebesar $2 \mathrm{mg} / \mathrm{kg}$ bobot 
Tabel 1. Rata-rata aktivitas kholin esterase serum darah itik pada 0, 30 dan 60 hari setelah diberi ransum dengan tiga macam aras cemaran diazinon (KU/l)

\begin{tabular}{lcccc}
\hline Waktu pengamatan (hari ke-) & \multicolumn{3}{c}{ Aras diazinon } & \\
\cline { 2 - 4 } & $\mathrm{I}:(0 \mathrm{ppm})$ & $\mathrm{II}:(0,03 \mathrm{ppm})$ & $\mathrm{III}:(14 \mathrm{ppm})$ & Rata-rata ${ }^{\mathrm{ns}}$ \\
0 & 2,023 & 1,711 & 1,990 & 1,908 \\
30 & 2,254 & 1,925 & 2,705 & 2,295 \\
60 & 2,073 & 1,624 & 2,109 & 1,936 \\
\hline Rata-rata $^{\text {mis }}$ & 2,117 & 1,754 & 2,268 & \\
\hline
\end{tabular}

${ }^{n s}$ Berbeda tidak bermakna

Tabel 2. Kadar Hb, RBC, PVC, MHC dan MCHC darah itik yang diberi pakan dengan tiga aras cemaran diazinon

\begin{tabular}{lccc}
\hline Parameter & \multicolumn{3}{c}{ Aras diazinon } \\
\cline { 2 - 4 } & $\mathrm{I}:(0 \mathrm{ppm})$ & II $:(0,03 \mathrm{ppm})$ & III $:(14 \mathrm{ppm})$ \\
$\mathrm{Hb}(\mathrm{g} / \mathrm{dl})$ & $9,1^{\mathrm{a}}$ & $10,3^{\mathrm{b}}$ & $8,9^{\mathrm{a}}$ \\
$\mathrm{RBC}\left(10^{12} / \mathrm{l}\right)^{\mathrm{ns}}$ & 2,60 & 2,85 & 2,80 \\
$\mathrm{PVC}(\%)^{\mathrm{ns}}$ & 36,3 & 39,0 & 37,0 \\
$\mathrm{MCH}(\mathrm{pg})^{\mathrm{ns}}$ & 36,0 & 36,83 & 32,02 \\
MCHC $(\mathrm{g} / \mathrm{dl})$ & $24,94^{\mathrm{a}}$ & $26,53^{\mathrm{b}}$ & $24,24^{\mathrm{a}}$
\end{tabular}

${ }^{\mathrm{n}}$ Berbeda tidak bermakna

ab Superskrip yang berbeda pada baris yang sama menunjukkan perbedaan bermakna

badan (Haryono dkk., 1982). Dalam penelitian ini konsumsi diazinon pada itik kelompok P III masih di bawah dosis letal. Aras cemaran diazinon yang rendah dan waktu konsumsi yang relatif singkat memungkinkan ensim kholin esterase yang terfosforilasi oleh diazinon belum cukup banyak atau belum sempat mengalami aging, sehingga komplek ensim fosfat dapat dihidrolisis kembali menjadi ensim yang teregenerasi dan senyawa yang bersifat toksik yaitu asam diethilthiofosfat (Cassaret dan Doull, 1975).

\section{Gambaran Fisiologis Darah Itik}

Kadar $\mathrm{Hb}, \mathrm{RBC}, \mathrm{PCV}, \mathrm{MCH}$ dan $\mathrm{MCHC}$ darah itik yang diberi pakan dengan cemaran tiga aras diazinon disajikan dalam Tabel 2.

Jumlah sel darah merah itik berbeda tidak bermakna sebagai akibat pemberian diazinon dalam ransum, hal ini mungkin disebabkan aras cemaran diazinon dalam ransum rendah. Emst dan Ringer (1968) melaporkan bahwa puyuh yang diberi pakan dengan cemaran insektisida organofosfat zytron sebesar $2000 \mathrm{ppm}$ selama 12 hari mempunyai sel darah merah yang sangat berbeda dengan kontrol.

\section{Kadar Kholesterol Darah dan Telur}

Kadar kholesterol darah dan telur itik setelah diberi ransum dengan tiga aras cemaran diazinon disajikan dalam Tabel 3

Meskipun cemaran diazinon dalam pakan tidak mempengaruhi kadar kholesterol darah namun secara bermakna menyebabkan penurunan kadar kholesterol telur. $\mathrm{Hal}$ ini dapat dipahami karena diazinon dapat berfungsi sebagai inhibitor kompetitif untuk ensim lipase. Ensim lipase adalah ensim yang mampu menghidrolisis ikatan ester triasil gliserol menjadi asam lemak dan gliserol. 
Tabel 3. Kadar kholesterol darah dan telur itik setelah diberi ransum dengan tiga aras cemaran diazinon (\%)

\begin{tabular}{|c|c|c|c|}
\hline \multirow[t]{2}{*}{ Parameter } & \multicolumn{3}{|c|}{ Aras diazinon } \\
\hline & I: $(0 \mathrm{ppm})$ & II : $(0,03 \mathrm{ppm})$ & III : (14 ppm) \\
\hline Darah $(\mathrm{mg} / 100 \mathrm{ml})^{\mathrm{ns}}$ & 174,90 & 158,54 & 157,12 \\
\hline Telur $(\mathrm{mg} / 100 \mathrm{~g})$ & $279,82^{\mathrm{a}}$ & $174,62^{b}$ & $128,39^{\circ}$ \\
\hline \multicolumn{4}{|c|}{$\begin{array}{l}\text { Berbeda tidak bermakna } \\
{ }^{\text {mbc }} \text { Superskrip yang berbeda }\end{array}$} \\
\hline \multicolumn{4}{|c|}{$\begin{array}{l}\text { Tabel 4. Kadar lemak, kadar protein, kadar air dan kadar abu daging itik } \\
\text { setelah diberi ransum dengan tiga aras cemaran diazinon }(\%)\end{array}$} \\
\hline \multirow[t]{2}{*}{ Parameter } & \multicolumn{3}{|c|}{ Aras diazinon } \\
\hline & I : $(0 \mathrm{ppm})$ & II : $(0,03 \mathrm{ppm})$ & III : (14 ppm) \\
\hline Kadar Lemak ${ }^{\mathrm{ms}}$ & 3,072 & 2,743 & 3,117 \\
\hline Kadar Protein ${ }^{\text {ss }}$ & 20,438 & 20,815 & $21,385^{\circ}$ \\
\hline Kadar Air ${ }^{n s}$ & 73,335 & 73,627 & 71,820 \\
\hline Kadar Abu ${ }^{\text {ns }}$ & 1,313 & 1,377 & 1,389 \\
\hline
\end{tabular}

${ }^{\mathrm{ma}}$ Berbeda tidak bermakna

Dengan $\beta$-oksidasi asam lemak akan dipecah menjadi asetil KoA yang merupakan prekusor sintesis kholesterol (Lehninger, 1975). Dengan semakin banyaknya diazinon yang dikonsumsi, semakin banyak lipase terhambat yang pada akhirnya akan menghambat sintesis kholesterol terutama kholesterol telur, sedangkan kholesterol darah masih dapat dipertahankan dengan adanya pengaturan homeostasis.

\section{Komposisi Kimia Daging}

Kadar lemak, kadar protein, kadar air dan kadar abu daging itik setelah diberi ransum dengan tiga aras cemaran diazinon disajikan dalam Tabel 4.

Kadar lemak menunjukkan perbedaan yang tidak bermakna sampai aras diazinon 14 ppm. Hal ini mungkin disebabkan karena dengan adanya diazinon yang menghambat kerja lipase. Lemak daging tidak banyak mengalami pembongkaran, sehingga meskipun kholesterol telur menurun nampaknya tidak ada transfer asetil KoA dari lemak simpanan dalam daging. Dengan tidak berubahnya kadar lemak daging maka komposisi kimia daging lainnya relatif tetap.

\section{Kesimpulan}

1. Cemaran diazinon sampai aras $14 \mathrm{ppm}$ dalam ransum tidak berpengaruh terhadap aktivitas kholin esterase, performan, gambaran darah dan komposisi kimia daging.

2. Cemaran diazinon dalam ransum menyebabkan penurunan kholesterol dalam telur meskipun kholesterol darah dapat dipertahankan.

\section{Ucapan Terima Kasih}

Dengan ini diucapkan terima kasih kepada Saudara Handoyo, Yohanes Tiono, Dadik Pataya atas partisipasinya dalam pelaksanaan penelitian. 


\section{Daftar Pustaka}

Cassaret, L. J. And J. Doull. 1975. Toxicology, The Basic. Science of Poisons. Mac Milan. Publ., Co., Inc. New York.

Emst, R. A and R. K. Ringer, 1968. The Effect of DDT, zetran and zytron on the PCV, total erythrocyte count and mean corpuscular volume of Japanese quail Poul. Sci. $47: 630: 643$

Harrie, L. E. 1970. Chemical and Biological Methods for Feed Analysis, Center for Tropical Agriculture. Feed Composition. Project, Live Stock Pavilion University of Florida, USA.

Haryono, B. W. T. Artama, dan S. Haryanto. 1982. Pengaruh Pemberian Diazinon Per-Oral, secara Kronik terhadap Kadar SGPT dan SGOT kelinci. Dalam Penelitian Biokimia Lingkungan Hidup dan Pembangunan Nasional. Proceeding Seminar Nasional IV Biokimia. 811 Agustus 1982. ITB.

Hodgson, E. and F. E. Guthrie. 1976. Introduction to Bhiochemistry Toxicology. Elsevier North Holland. Inc. New York. USA.
Lehninger, A. L. 1975. Biochemistry. $2^{\text {nd }}$ ed. Wort Publisher. Inc. New York. USA.

Miller, A. R. 1963. Meat Hygiene. $2^{\text {nd }}$ ed. Lea Fibiger. Philadelphia. USA.

Oksawa, K, S. Hartadi, S. Noegrohati, H. Sastrohamidjojo, K. Untung, N. Arya, K. Sumartha and S. Kawatsuka. 1985. Residu Analysis of organochlorine and organophosphorus pesticides in soils, waters and vegetables from central Java and Bali Island. Ecological Impact of Pest Nanage Ment in Indonesia. p. 59 70. Tokyo University of Agriculture. Japan.

Plummer, D. T, 1977. An Introduction To Practical Biochemistry. McGraw Hill Book Co.Ltd. New Delhi

Simon, S. 1984. Analisa Residu Peptisida Azodrin dan Diazinon dalam Air Sawah dengan Khromatografi Gas. Skripsi. Fakultas Peternakan UGM

Soehardi, M. dan M. Sumatera. 1982. Masalah Residu Peptisida pada Produk Hortikultura. Makalah Simposium Entomologi p. 1-26. Perhimpunan Entomologi Indonesia. Bandung

Stryer, L. 1975. Biochemistry, $1^{\text {st }}$ ed. W.A. Freeman and Company. San Fransisco. USA 